\title{
KNOWLEDGE MANAGEMENT - EDUCATION IN THE LIGHT OF INDUSTRY 4.0
}

doi: $\quad 10.2478 /$ czoto-2019-0123

Date of submission of the article to the Editor: 03/12/2018

Date of acceptance of the article by the Editor: 28/01/2019

\author{
Anna Wiśniewska-Sałek ${ }^{1}$ - orcid id: 0000-0003-4537-3225 \\ ${ }^{1}$ Czestochowa University of Technology, Poland, anna.wisnieska-salek@wz.pcz.pl
}

\begin{abstract}
Education of young generation, aimed at teaching how to manage own knowledge in the economy, is a great challenge for the teaching staff at each stage of education. The paper is to analyze the data describing the selection of development path of pupils and students. Comparing them with the expectations set up by the market through the implementation of the concept of Industry 4.0 will allow the estimation of whether the technical education offer (in the area of Industrial Engineering) is a sufficient response to the economic preferences relating to employment.
\end{abstract}

Keywords: knowledge management, Industry 4.0, education, MSIE 4.0

\section{INTRODUCTION}

The issue of Industry 4.0 is the one extensively analyzed and described ( $\mathrm{Li} \mathrm{Da} \mathrm{Xu} \mathrm{et}$ al., 2018; Ślusarczyk, 2018; Roblek et al., 2016; Lasi et al., 2014; Paprocki, 2016). Its assumptions, among others, relate to automation and digitization of processes in enterprises (Davis et al., 2012; Yin et al., 2018; Chiarvesio and Romanello, 2018; Almada-Lobo, 2016), construction of business models (Fettermann et al., 2018) or relationships between automation and the employer (Ghislieri et al., 2018). Rapid progress in industrialization in connection with the methods used in computerization contributed to significant progress in the development of the new generation of production technology. The Fourth Industrial Revolution is reaching its peak capabilities and the implementation processes in enterprises are progressing rapidly. In the whole process of changes, sustainable development (Julian M. Müller, Kai-Ingo Voigt. (2018) should perform the role of a certain border, which will optimize the use of natural resources but will also equally take care of production and social development in enterprises and the economy. Education, considered as a form of social development described in the context of knowledge management should similarly adapt to economic trends like technology (Kulej-Dudek, 2013; Lis et al., 2017; Klimecka-Tatar and Ulewicz, 2014; Wiśniewska-Sałek, 2017, Pacana and Ulewicz, 2017). The flexibility of the education market is however so difficult that it is hard to predict, in an approximately 20-year education cycle, how market trends will change and they are known to change. Therefore, it seems well-grounded to conduct 
the process of education of interdisciplinary profiles to be able, at the university level, to formulate a specialization and, after commencing employment, to carry on "lifelong learning".

\section{THE CHARACTERISTICS OF EDUCATION IN POLAND - LEGISLATION}

The education process in Poland is divided into the educational system and the higher education system. The educational system, in accordance with the Law on education, includes (Art. 2):

- kindergartens;

- schools: primary, secondary, art;

- education and care establishments; continuing education; art;

- psychological and pedagogical counseling centers;

- youth educational centers;

- facilities providing care and education to students in the period of education outside the place of permanent residence;

- teacher training institutions;

- pedagogical libraries;

- colleges of social workers.

The educational reform introduced in 2017 ultimately aimed at the division of public and private schools according to the following types (Art.18):

- eight-year primary school;

- secondary schools:

- four-year general education secondary school,

o five-year technical secondary school,

o three-year first cycle degree vocational school,

o three-year special vocational preparatory school,

o two-year second cycle degree vocational school,

- a post-secondary school for people with secondary education or secondary vocational education, with the education period of not more than 2.5 years.

In accordance with the assumptions of the legislator, the educational system - after completing primary education - provides an opportunity to direct the future occupational pathway in several options (http://reformaedukacji.men.gov.pl):

I. 3-year special vocational preparatory school $\rightarrow$ employment;

II. 3-year first cycle degree vocational school $\rightarrow$ employment;

Ila. 3-year first cycle degree vocational school $\rightarrow$ 2-year second cycle degree vocational school $\rightarrow$ employment;

Ilb. 3-year first cycle degree vocational school $\rightarrow$ 2-year second cycle degree vocational school $\rightarrow$ university $\rightarrow$ employment;

III. 5-year technical secondary school $\rightarrow$ employment;

IIla. 5-year technical secondary school $\rightarrow$ university $\rightarrow$ employment;

IV. 4-year general education secondary school $\rightarrow$ employment;

IVa. 4-year general education secondary school $\rightarrow$ 1-2.5- year post-secondary school $\rightarrow$ employment;

IVb. 4-year general education secondary school $\rightarrow$ 1-2.5-year post-secondary school $\rightarrow$ university $\rightarrow$ employment. 
The selection of the school type made by students (supported by parents) until reaching the age of about 20 years by them is of great importance while taking a decision on starting a permanent job or continuing education at university.

Higher education, according to the Law on higher education and science divides universities into public and private: academic or vocational (Art.13).

In higher education in Poland, like in the educational system, there was conducted the reform, which has been in force since the academic year of 2018/2019. In the view of the above, academic universities conduct scientific activities whereas vocational colleges provide the education compliant with the needs of the socio-economic environment (Art. 14 and 15).

The legislator, in Articles 64 and 65 of the Law, lists the stages (time) at which the university education is conducted:

- undergraduate (first cycle degree program) (at least 3 years and for engineering competences - 3.5 years);

- graduate (second cycle degree program) (from 1.5 to 2.5 years);

- long-cycle Master's degree program (from 4.5 to 6 years);

and specifies the profile of the conducted university education:

- practical in relation to which more than half of ECTS points are assigned to classes building practical skills;

- general academic, where more than half of ECTS points are assigned to classes associated with scientific activities conducted at university.

Compulsory education in Poland is specified by Art. 35 (2) - schooling obligation of a child starts at the beginning of the school year in the calendar year in which the child reaches the age of seven and continues until the completion of a primary school but not longer than until the age of eighteen.

Building an educational pathway with a view to preparing to start building a professional career lasts for about 18-21 years. Therefore, acquiring expertise and skills seems to be possible while taking into account the time. The management of knowledge acquired during the education process seems to be possible due to the variety of options provided by the legislator. The problem, however, is the selection of the school/university profile to make it consistent with the expectations of the economy.

\section{SCHOOLS AND UNIVERSITIES IN POLAND - THE ANALYSIS}

Industry 4.0 has certain assumptions and is a dynamic process. The education system adapted to the market requirements of Industry 4.0 will allow the employment of interdisciplinary skilled workers. These actions require focusing on the education of engineers with not only technical knowledge but also with communication skills.

The current state of education in Poland in the field of educating the future "Engineer 4.0" will relate to the examination of the offer of schools and universities in 2017. Due to the fact that 3 October 2018 was the deadline for the transmission of educational databases in the educational information system as of 30 September 2018, the analysis of data in the paper will relate to the publicized number of schools as of 30 September 2017.

The number of schools educating young people and adults above primary school amounts to 14589 facilities (the detailed division is shown in Figure 1). Each facility has sections (forms) which, in accordance with the definition of the Central Statistical 
Office, must be understood as "the basic organizational school unit. In school, the section is a group of students being educated in the same class" (http://stat.gov.pl)

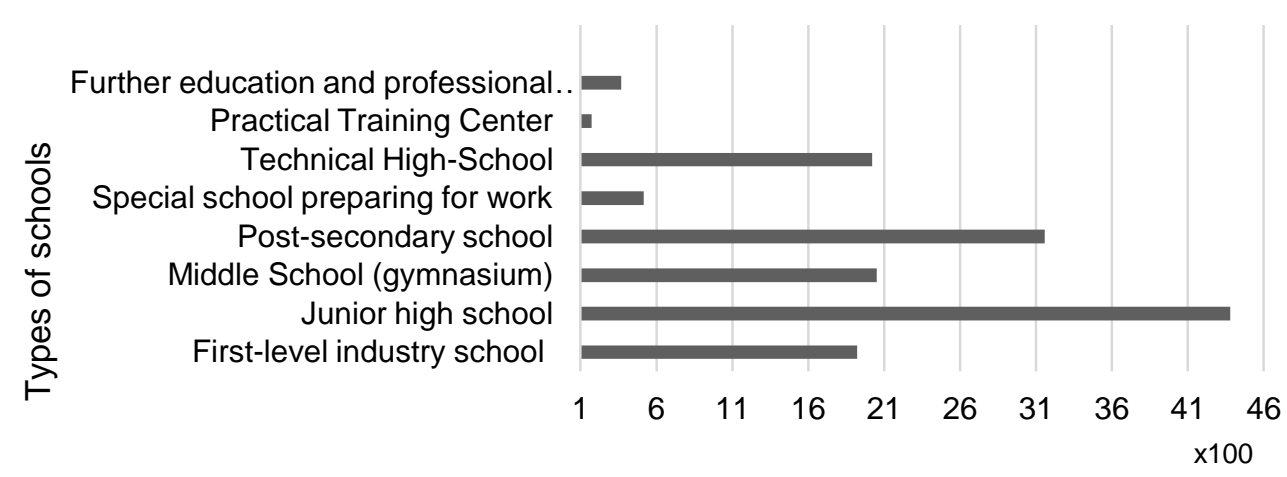

Quantity of schools

Fig. 1. Quantity of schools divided into types of schools in Poland in 2017 (based on data published on the website of Information Center of Education)

The number of individual sections (tab. 1) is the measure of diversified or unidirectional profiles of education, which, in the case of industry, is a quite important aspect.

Table 1

The average number of branches per school type in Poland in 2017

\begin{tabular}{|c|c|}
\hline Types of schools & Number of branches \\
\hline First-level industry school & $5-26^{*}$ \\
\hline Secondary school & 6 \\
\hline Junior high school & 4 \\
\hline Post-secondary school & 6 \\
\hline Special school preparing for work & 3 \\
\hline Technical High-School & 11 \\
\hline
\end{tabular}

Source: Data published on the website of Information Center of Education

While analyzing the information, it can be concluded that the profile of education is rather narrow per less than 15000 schools, therefore, it relates to students' general education. A significant number of general education schools has only about six sections and only three facilities preparing for work. Such a structure may pose a certain problem in terms of possessing specific knowledge or skills in the context of education at the university level. Too general knowledge of a particular industry may lead to the selection of major which is not consistent with the expectations and, at the same time, the actual lack of readiness to start a job.

Therefore, the process of building curricula at universities should firstly take into account the introductory structure which would profile the target effect of the competences possessed and then the professional structure which would define the detailed education compliant with the requirements of the economy. The number of universities in Poland in 2017 amounted to 397 (Figure 2) and the number is 
decreasing from year to year. Declines most affect the universities with economic, pedagogical and vocational profile (PWSZ University).

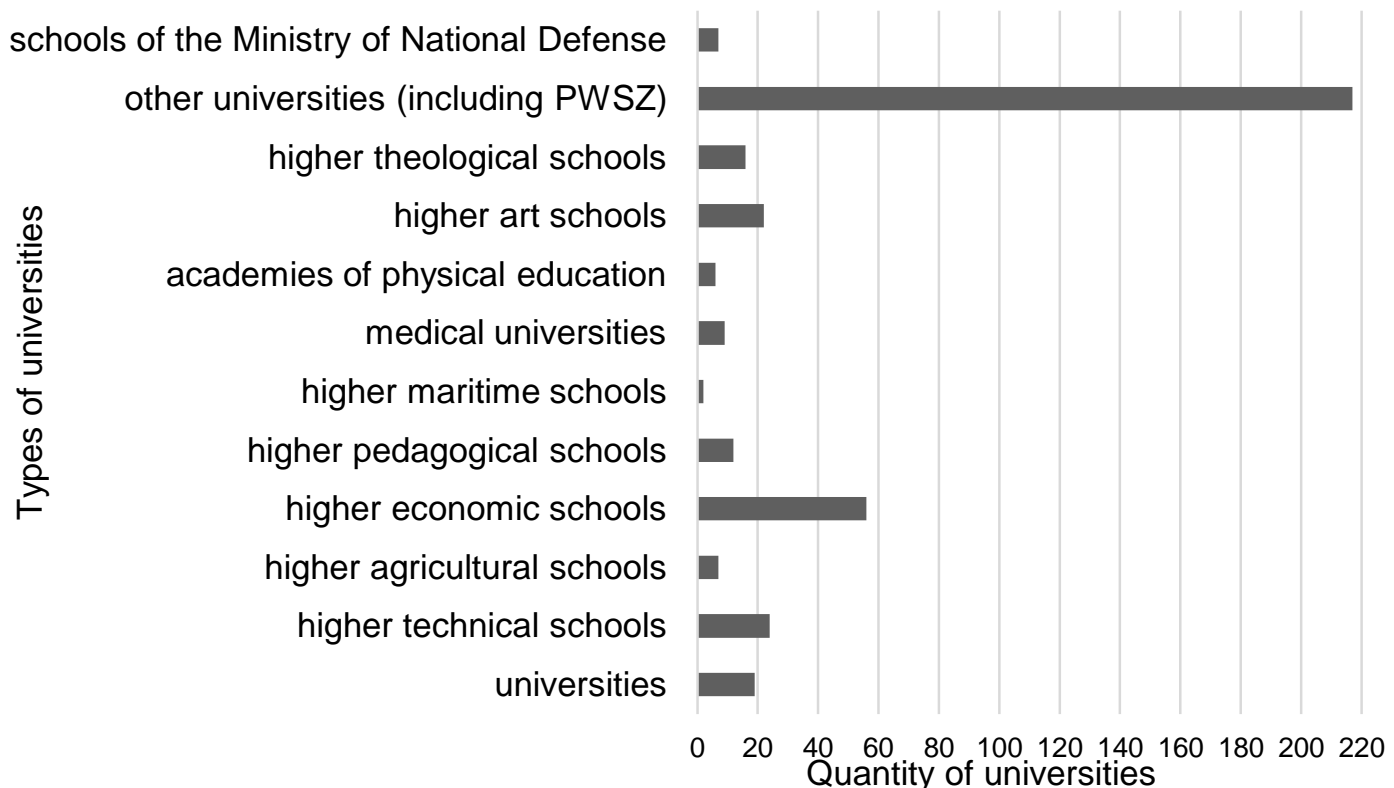

Fig. 2. The number of universities divided into types of universities in Poland in 2017 (Based on data published on the CSO website - Local Data Bank)

In the context of the number of schools or universities, the number of pupils/students/ course participants is also important. The demographic decline in Poland in recent years and the nature of the society defined as "aging" (compare: Wiśniewska-Sałek A., 2017) brings about that, by definition, the share of the people learning is lower. An important relationship in the case of the teaching process and readiness to start a job is the ratio of the number of people starting education and the number of graduates. In 2017671233 students completed their education at the secondary education level, which amounted to $26 \%$ of the student population in 2017. In turn, in 2012 the number of students was 3351630 and the number of graduates was only 7746645 years later (the detailed division is shown in Figure 3).

On the basis of the data, it can be concluded that individual types of universities have a relatively stable percentage of graduates at the university level. While comparing the number of students in 2012 with the number of those studying in 2017, it also cannot be noted that selected majors register major changes. Therefore, it can be concluded that students' interests do not change and the decline results from demographic trends.

In relation to Industry 4.0, however, one needs to wonder whether the education in Poland is oriented properly, if the trends of major repeatability in the context of qualifications possessed by teachers and selection of stable majors by learners are good, whether one ought to strive for constant detailing or otherwise fragmenting the issues describing a specific industry and the related job and thus respond to economic preferences. 


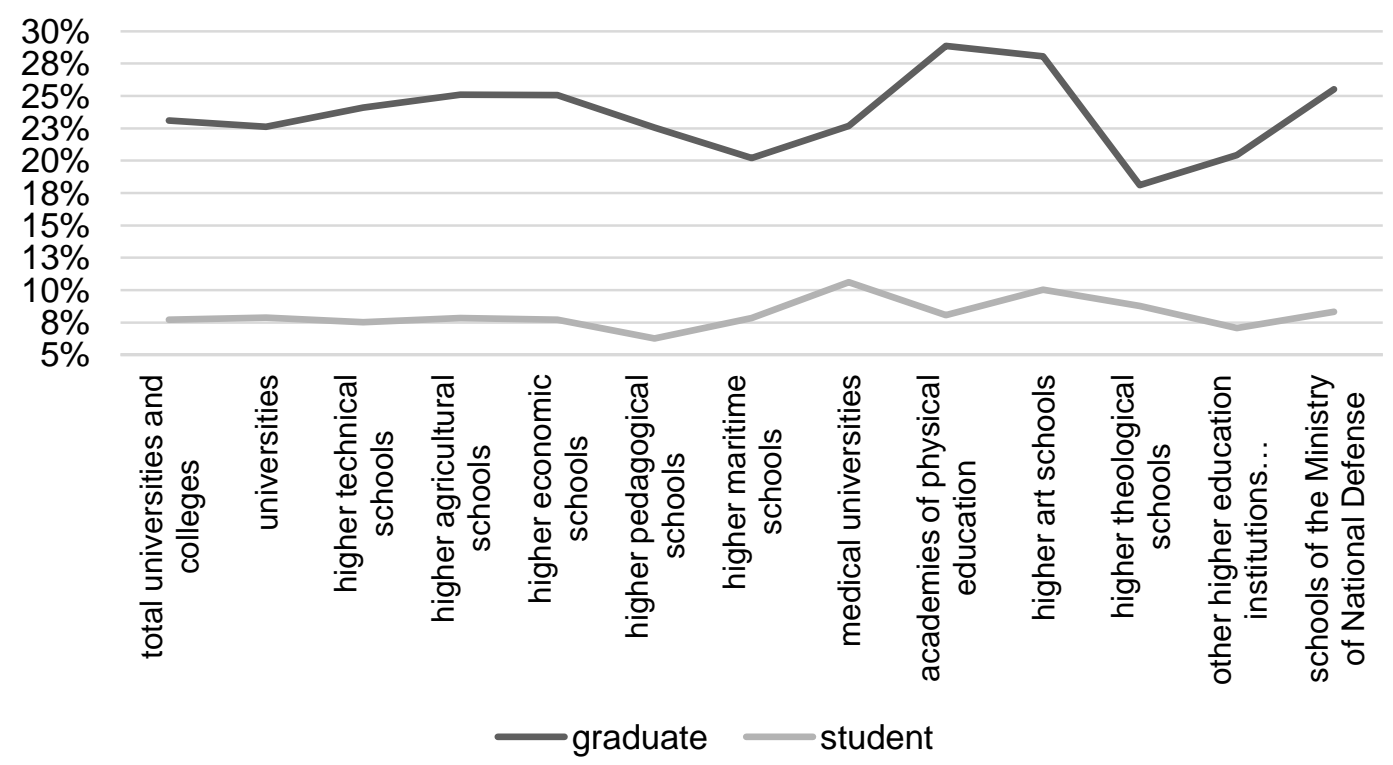

Fig. 3. Percentage of the number of students and graduates by type of university in Poland in relation to 2012 by 2017. (Based on data published on the CSO website - Local Data Bank)

\section{CONCLUSIONS}

Knowledge management interpreted by the author in the context of the paper, as managing own education so as to start a job consistent with own requirements but also the needs of the economy in the future, having appropriate knowledge and competences, is not an easy decision-making process. In accordance with the research results publicized by the "Astor" company (Astor, 2017), Germany is listed as one of the three countries being the leaders among competitors of research and development centers of Industry 4.0. On the basis of the research of German companies (considered as leaders in the production of industrial equipment and top suppliers of software for companies) referring to "digital transformation", it has been noticed that the greatest opportunity in the process of creating an additional value for the enterprise is combining the management level (vision and skills they represent) with engineering and operational (identified with their knowledge, imagination and abilities to use technologies). Therefore, it can be concluded that the key group, which will enable the implementation of the concept of industry 4.0 in enterprises, are engineers - in particular their knowledge, competences and motivation. While relating to the realities of the Polish economy and entities constituting it, in 2016 the Astor company conducted the research aimed at characterizing the "Engineer 4.0". The analysis of the obtained data allowed the formulation of the conclusions: developing technical skills; development through knowledge outside the area of own specialization; development of competences associated with communication and skills in conducting an activity by means of e.g. work organization. Employees who will take part in "digital transformation" must pay attention to their attitude towards readiness and openness to changes and flexibility of their adaptation, as well as expand their knowledge, not only technical but also the one which includes other disciplines.

Taking into account the results of the research into schools and universities in Poland, in the context of educating a future engineer 4.0 , it can be acknowledged that a 
certain lack of changeability in selecting the courses of education seems to be a good method of own knowledge management.

The process of knowledge management in the context of Industry 4.0 can be brought to the following structure: primary school (general knowledge), secondary school (professional knowledge), university (expertise). It is important for the whole level of education to introduce the element of interdisciplinarity, for example, in technical secondary schools, not to limit education to practical learning of a profession but also to show the significance of a profession in the process of building the economy. In turn, management staff should not limit themselves only to managing teams but also they ought to learn the specificity of technical work so as to assign task properly and assess them objectively.

A good example of building new curricula is intercultural cooperation. The practices that can be observed in other European and non-European countries, e.g. in building curricula while taking into account the needs of the economy, are confirmed by the results of the research conducted by the Astor company. An example of such activities is one of the projects co-financed from the EU funds. The assumption of MSIE4.0 is to increase the capacity and productivity of universities in Thailand to provide high quality teaching programs - based on competences, for MA studies in the field of industrial engineering, which are supported by sustainable intelligent industry (Industry 4.0) compliant with the European qualification frameworks (European Qualifications Framework - EQF) (https://msie4.ait.ac.th).

\section{ACKNOWLEDGEMENTS}

This publication is a partial outcome of project "Curriculum Development of Master's Degree Program in Industrial Engineering for Thailand Sustainable Smart Industry (MSIE4.0)" that has been funded with support from the European Commission (Project Number: 586137-EPP-1-2017-1-TH-EPPKA2-CBHE-JP).

\section{Disclaimer}

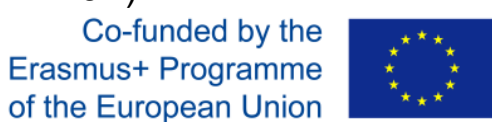

This publication reflects the views only of the authors, and the Commission cannot be held responsible for any use which may be made of the information contained therein.

\section{REFERENCES}

Almada-Lobo, F., 2016. The Industry 4.0 revolution and the future of manufacturing execution systems (MES). Journal of Innovation Management, 3, 16-21. http://hdl.handle.net/10216/81805

Chiarvesio, M., Romanello, R., 2018. Industry 4.0 Technologies and Internationalization: Insights from Italian Companies. International Business in the Information and Digital Age. Progress in International Business Research, 13, Publisher: Emerald Publishing Limited, 357-378. DOI: 10.1108/S1745886220180000013015

Davis, J., Edgar, T., Porter, J., Bernaden, J., Sarli, M., 2012. Smart manufacturing, manufacturing intelligence and demand-dynamic performance. Computers and Chemical Engineering, 47, 145-156. DOI: 10.1016/j.compchemeng.2012.06.037

Fettermann, D.C., Gobbo Sá Cavalcante, C., Domingues de Almeida, T., Tortorella, G.L., 2018. How does Industry 4.0 contribute to operations management? 
Journal of Industrial and Production Engineering, 35, 4, 255-268. DOI: 10.1080/21681015.2018.1462863

Ghislieri, C., Molino, M., Cortese, C.G., 2018. Work and Organizational Psychology Looks at the Fourth Industrial Revolution: How to Support Workers and Organizations? Frontiers in Psychology 9, 2365. DOI: 10.3389/fpsyg.2018.02365

Klimecka-Tatar, D., Ulewicz, R., 2014. The Quality of Education at the Universities. In: Borkowski, S., Rosak-Szyrocka, J. (eds) "Evaluation of People and Products Features", University of Maribor, Faculty of Logistics, Celje, 56-68.

Kulej-Dudek, E., 2013. Evaluation of knowledge management in small and mediumsized enterprises. Polish Journal of Management Studies, 8, 168-174.

Lasi, H., Fettke, P., Kemper, H.G., Feld, T., Hoffmann, M., 2014. Industry 4.0. Business \& Information Systems Engineering, 6, 4, 239-242, DOI: 10.1007/s12599-014-0334-4

Li Da Xu, Eric L. Xu, Ling Li, 2018. Industry 4.0: state of the art and future trends. International Journal of Production Research 56, 8, 2941-2962, DOI: 10.1080/00207543.2018.1444806

Lis, T., Bajdor, P., Ptak, A., 2017. Zarządzanie w przestrzeni informacyjnej a efektywność zarządzania wiedzą w przedsiębiorstwie. In: Perechuda, K., Chomiak-Orsa, I. (eds), „Wiedza menedżerska i technologie informacyjne w biznesie", Wydawnictwo WZPCz, Częstochowa, 25-34.

Müller, J.M., Voigt, K-I., 2018. Sustainable Industrial Value Creation in SMEs: A Comparison between Industry 4.0 and Made in China 2025. International Journal of Precision Engineering and Manufacturing-Green Technology 5, 5, 659-670. DOI: $10.1007 / \mathrm{s} 40684-018-0056-z$

Pacana, A., Ulewicz, R., 2017. Research of determinants motiving to implement the environmental management system. Polish Journal ff Management Studies, 16,1, 165-174. DOI: 10.17512/pjms.2017.16.1.14

Paprocki, W., 2016. Koncepcja Przemyst 4.0 i jej zastosowanie w warunkach gospodarki rynkowej. In: Gajewski, J., Paprocki, W., Pieriegud, J. (eds.), "Cyfryzacja gospodarki i społeczeństwa. Szanse i wyzwania dla sektorów infrastrukturalnych", Publikacja Europejskiego Kongresu Finansowego, Gdańsk.

Roblek, V., Meško, M., Krapež, A., 2016. A complex view of industry 4.0. SAGE Open, 6, 2, 1-11. DOI: 10.1177/2158244016653987

Ślusarczyk, B., 2018. Industry 4.0 - Are We Ready? Polish Journal of Management Studies, 17,1, 232-248, DOI: 10.17512/pjms.2018.17.1.19

Wiśniewska-Sałek, A., 2017. Education Management - The Analysis of the Economic Potential of the Silesian Region. In: Slavíčková, P. (ed), "Knowledge For Market Use 2017: People In Economics - Decisions, Behavior And Normative Models". International Scientific Conference Proceedings, Palacký University, Olomouc, 506-515.

Yin, Y., Stecke, K.E., Li, D., 2018. The evolution of production systems from Industry 2.0 through Industry 4.0. International Journal of Production Research, 56, 1-2, 848-861. DOI: 10.1080/00207543.2017.1403664

Dz. U. 2017 poz.59 USTAWA z dnia 14 grudnia 2016 r. Prawo oświatowe

Dz. U. 2018 poz. 1668 USTAWA z dnia 20 lipca 2018 r. Prawo o szkolnictwie wyższym i nauce. Ustawa wchodzi w życie w terminie i na zasadach określonych w ustawie z dnia 3 lipca 2018 r. - Przepisy wprowadzające ustawę - Prawo 0 szkolnictwie wyższym i nauce (Dz. U. poz. 1669) 
http://reformaedukacji.men.gov.pl/wp-content/uploads/2016/11/plakat-reforma.jpg http://stat.gov.pl/en/metainformations/glossary/terms-used-in-official-

statistics/list.html\#letterS

https://bdl.stat.gov.pl/BDL/start

https://cie.men.gov.pl/sio-strona-glowna/podstawowe-informacje-dotyczce-wykazuszko-i-placowek-owiatowych/wykaz-wg-typow/

https://msie4.ait.ac.th/ 